\title{
An Udmurt Exceptional Performer, Dzhakapay
}

\author{
Irina Pchelovodova \\ e-mail: orimush@mail.ru
}

Nikolai Anisimov

e-mail: nikolai.anisimov@folklore.ee; kyldysin@yandex.ru

\begin{abstract}
This article concentrates on the phenomenon of the individual in the ethnic culture of the Udmurt, bearing in mind that this has never been attempted before. This is a proper framework to analyse Ol'ga Solov'yova's (1932-2018) personality, who was famous among the people as Dzhaky / Dzhakapay / Dzhaky apay (lit: Aunt Jay). A whole range of reasons justifies scientific interest in her: her huge repertoire of songs and rituals, her ability to improvise freely within her local tradition, her unique musical and auditory skills.

The analysis of Dzhakapay's character allows us to connect the songs of her repertoire and her fate. Many non-ritual songs are in fact autobiographical narratives, dedicated to reflexions on an unhappy fate, on being an orphan. A considerable number of songs in her repertoire belong to the category of so-called personal songs (in Russian: imennyye pesni, 'name songs'), which represent a kind of personal memoire in musical form. Another unique feature of this performer's art is her knowledge of songs from neighbouring villages in their original language (Russian, Mari, Tatar) and their translation into Udmurt.

Her knowledge of the local traditional rituals made her very important to the local community, in which she was deeply respected. Until the last day of her life, she followed the ontological positions, the rules
\end{abstract}


of behaviour, the canons of ritual and singing performance elaborated by tradition, and attempted to instil them into the people surrounding her. This awakened her genuine interest in the social and scientific milieu. And today, when she is no longer among us, her name is attached to many very different projects.

Keywords: biography, individual, performer's character, singing repertoire, Udmurt, tradition

\section{Dzhakapayez bure vayysa no s'ulmys' tau karysa Remembering Dzhakapay and thanking her from the heart}

In every people's culture, there are individuals who distinguish themselves because of their creative potential and their charisma. Often they have deeply individual signatures in performance and are able to accumulate and transmit the cultural heritage of their people. Therefore, "it is important to approach folk culture through the world of its makers, persons, individuals, creators" (Romodin 2009: 9). As Romodin justly observes, only by going back to the human, subjective principle (unlike the formal and theoretic investigation of folklore units) can we see the living, intrinsic and fundamental component of ethnic culture (ibid.). Moreover, "the interest towards the human being as a subject of cultural tradition can be seen as one of the expressive trends emerging in today's humanities" (Lichnost'... 2014: 5).

Recent investigations have revealed that in tradition there are different types of folk musician (balanced, expressively unbalanced, mixed (transitionary) (Romodin 2009)), different manifestations of individuality in folk musical culture (Zhulanova 2014), as well as different modes in narrative tradition (Alpatov 2014). There have also been very convincing investigations into other cultures (for example Juha Pentikäinen 1971; Pino 2000). We must acknowledge that in Udmurt ethnomusicology and folkloristics, there has yet been no special research dedicated to the creative individual in 
traditional culture. We can mention only research by Svetlana Starodubtseva "Oh, My Poor Grieving Heart" (songs from Natalia Vlasova's repertoire)" (Starodubtseva 1999). This article attempts partly to fill this gap.

Thus, our attention concentrates on the main features of one of the brightest and most charismatic personalities in Udmurt traditional culture, Ol'ga Nikolaevna Solov'yova (1932-2018), called Dzhakapay. This choice is justified by the fact that, firstly, Dzhakapay demonstrated a colossal knowledge of folklore and ethnographic material from her tradition. In addition, both of the article's authors are well acquainted with her and for some years visited her regularly. This allowed them to observe her in everyday life, to participate in ritual action, and to interview her repeatedly, recording in writing her comments across the years.

\section{Childhood, family}

Dzhakapay was born in 1932 in Karamas-Pel'ga (Udm. Ud'd'ad'i), Kiyasovo district in Udmurtia, where she is best known under the name Dzhaky / Dzhakapay / Dzhaky apay (lit: Aunt Jay). She received this ornithomorphic name at birth, according to an old Udmurt tradition in which children received bird, animal and plant names because of frequent child mortality and long-term child illness. According to Dzhakapay, several children in her family died one after another, after which her parents gave her the name of the jay, Dzhaky.

In 1942, when she was ten, she and her three-year-old brother were orphaned when her father was killed at the front and her mother died suddenly. The children managed to avoid the orphanage and lived instead with their grandfather at his home.

These were difficult years for them and they were obliged to go about the village asking the villagers for food; they never had good clothes at this time. Sometimes the local kolkhoz helped and gave 
Irina Pchelovodova, Nikolai Anisimov

them half a $p u d^{1}$ of flour from the mutual aid fund. The assistance given by the villagers themselves was irreplaceable and Dzhakapay frequently thanked them in her songs.

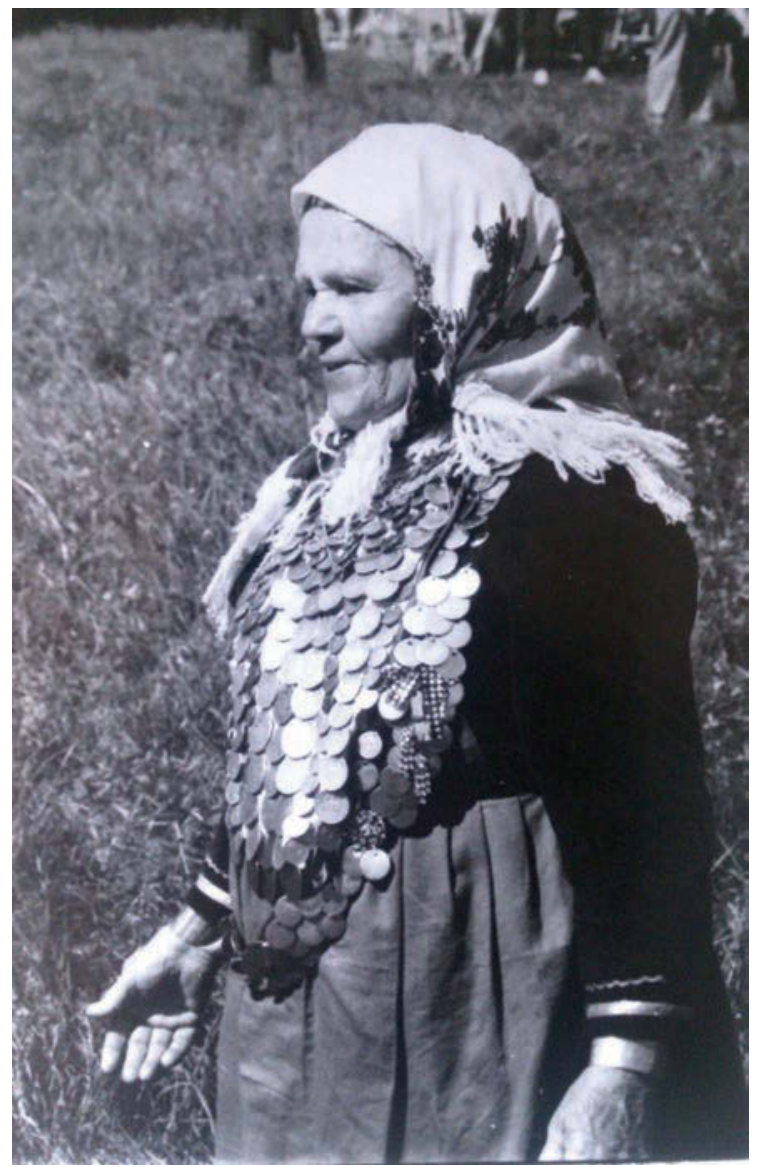

Photo 1. Dzhakapay - Ol'ga Solov'yova.

Photo from the Solov'yov family archive. 
As she remembered, on one of the hungry war days she decided to kill herself. However, an extraordinary event happened, and became a turning point in her fate:

Once I woke up early in the morning and I went out into the yard... My brother is small, my grandfather old. Then grandfather also died. We have no food, no clothes. The weather is windy. The neighbouring birch bends in different directions. To this day, I see this birch as my guardian angel. "Should I already die? What should I do?" I break down and weep. Then the birch seemed to answer me: "Do not die! Look at me: I bend down to the earth, and then I stand up, I straighten myself". At the same moment, without my noticing it, my brother came to me and said with tears in his eyes: "Sister, do not die! I shall never more weep or ask for food". These words remained in my heart for all my life.

Photo 2. Dzhakapay with her brother Semyon, 1954. Photo from the Solov'yov family archive.

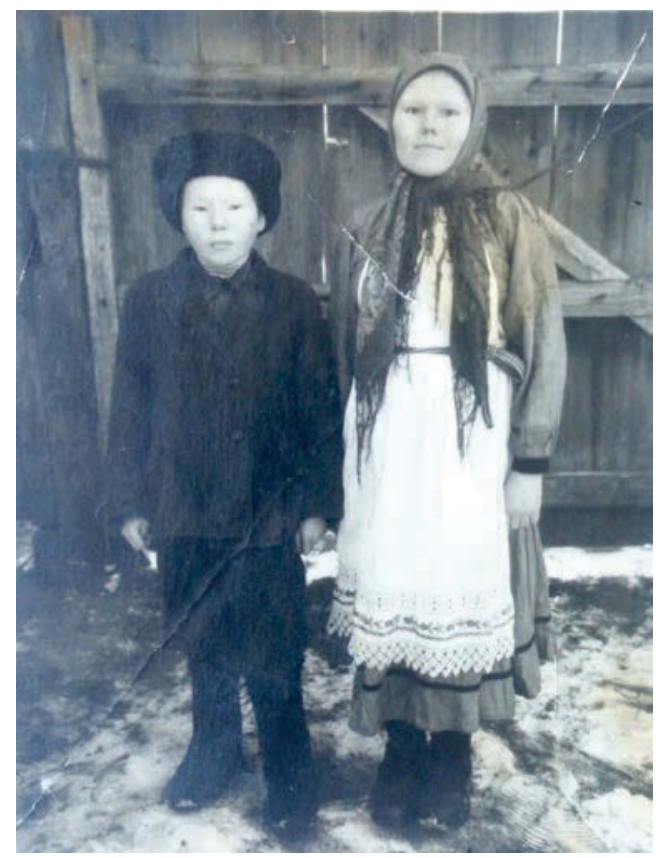


Because of the difficult circumstances of her life, Dzhakapay could not receive a full formal education, completing only four classes. But she promised herself that she would educate her brother Semyon Nikolaevich Utekhin. Semyon did indeed finish high school and went to university, to the Izhevk Agricultural Institute (now the Izhevsk State Agricultural Academy).

Dzhakapay married a man from the same village, a widower with six children. She did not have any children herself but raised her husband's children as her own. In addition, she took under her wing two of her brother-in-law's children who had become orphans.

She started her working life at the local kolkhoz, named Harvest (in Russian: urozhay, later renamed Lenin). She worked as a postman at the Karamas-Pel'ga liaison office receiving recognition for her work and her achievements: she was awarded the People's Friendship order and the medals For Labour Valour and Veteran of Labour. In 2005, she was awarded the title Kiyasovo District Citizen of Honour and in 2008 was given the Recognition award for her contribution to the development of folk art, bestowed by the government of the Udmurt Republic.

\section{Singing art and folk wisdom}

In Dzhakapay's hard fate, performing songs became her salvation. Through songs, she sang and shared her experiences, her concerns, her sorrows and her joys. This phenomenon reflects the Udmurt traditional psychology. Expressing emotions and thoughts through music is for the Udmurt a communicative channel that brings powerful cathartic and psychotherapeutic effects. In the psychology of the Udmurt, this is explained, according to ethnomusicologist Irina Nurieva, as a stereotypical Udmurt feature: "According to the rules of communication, the Udmurt, introverts by nature, are not allowed to express their emotions openly and loudly, to weep one's eyes out, to laugh loudly, to gesticulate widely" (Nurieva 2014: 206). Performing 
songs allows the Udmurt to express, to let out their inner state. These words are confirmed by what Dzhakapay herself says about singing:

I had not much experience of evening gatherings and funmaking. Partly I heard how my friends come back with songs from evening gatherings. But I composed songs in solitude, and I sang in my head. I even had no clothes to be in company. That's why I was very ashamed.... If I had not sung all this in my songs, I suppose I would not be alive with all the sorrows and hardness of life.

Many songs reflected her fate. In particular, she described the difficult period of her life in an autobiographical text using the tune from an Udmurt folksong. This song is close to the Udmurt lyric songs, reflecting on a sorrowful and unhappy fate. One of the main motifs expressing this state of mind is that of the orphan, who from a young age must go about among the people to earn herself a piece of bread to survive:

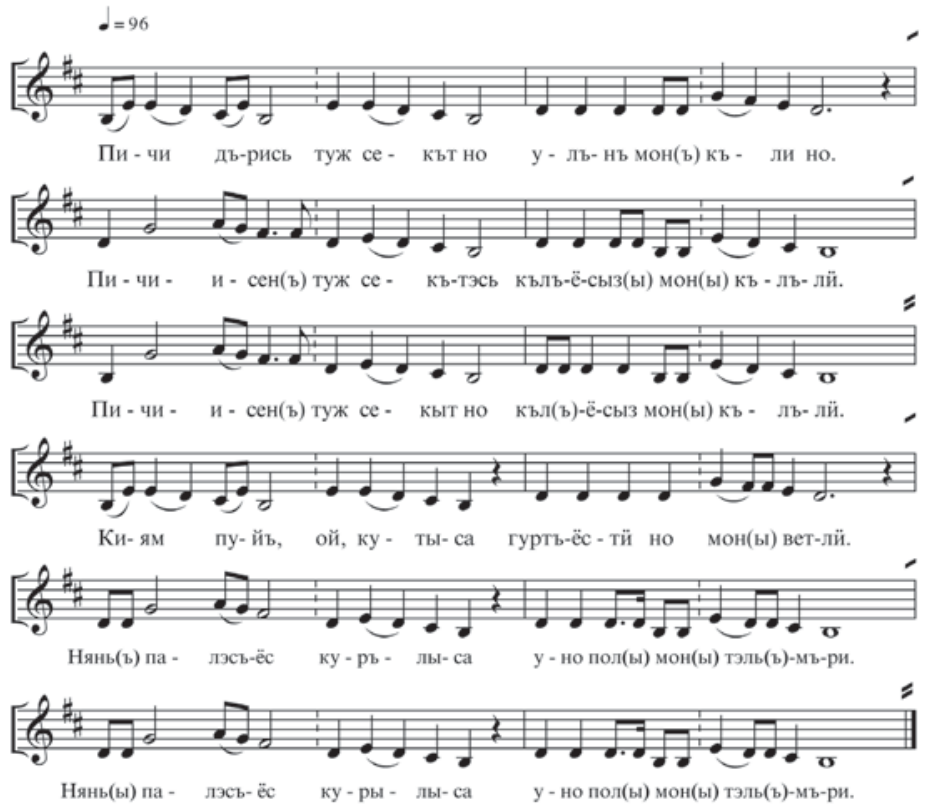


Pichi dyris' tuzh s'ekyt no Fromchildhooditisvery hard, and Ulyny mon(y) kyl'i no. I had to live, and.

Pichiis'en(y) tuzh s'ekytes' From childhood, very hard Kyl"yosyz(y) mon(y) kylyli. $\quad$ Words, yes, I heard.

Pichiis'en(y) tuzh s'ekyt no From childhood, very hard Kyl(y)yosyz mon $(y)$ kylyli. $\quad$ Words, yes, I heard.

Kiyam puyy, oy, kutysa, Taking in my hand, oh, a bag, Gurt"yosti no mon vetli. I went, yes, around the villages. N'an'(y) pales"yos kurylysa, Asking for crusts of bread, Uno pol(y) mon(y) tel'(y)myri. Many times I begged. N'an'(y) pales"yos kurylysa, Asking for crusts of bread, Uno pol(y) mon(y) tel'(y)myri. Many times I begged.

Bör(y)dis'ko no tshushis'kis'ko I weep and I dry my tears Töd'y vekchi kyshetam. With my thin white scarf. Mal(y)pas'kis'ko no paymis'ko I think and I wonder Yyrylen chidamezly. About the patience of my head Malpas'kis'ko no paymis'ko, I think and I wonder Yyrylen chidamezly. About the patience of my head ${ }^{2}$. (Kyrdzh'as'... 1995)

Frequently Dzhakapay used her songs to thank the people of her village because they did not allow her to quit the village, her father's house and her kin: 


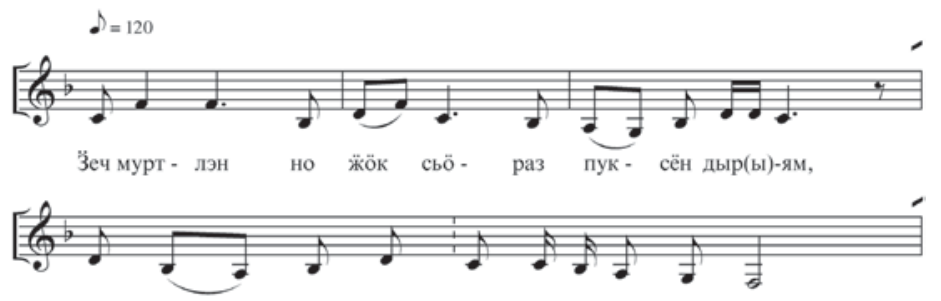

гурт ка - лы - ке- лы та - у ка - рись - ко.

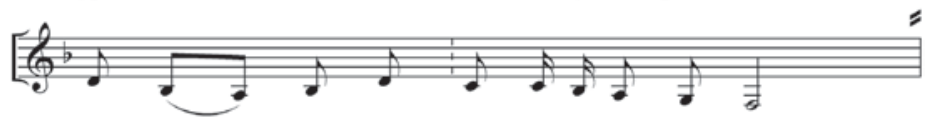

Гурт ка- лы - ке- лы та-у ка - рись - ко.

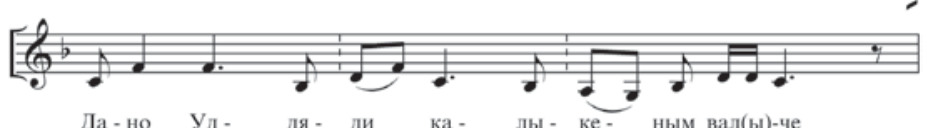

Да-но Уд- дя- ди ка- лы- ке- ным вал(ы)-че

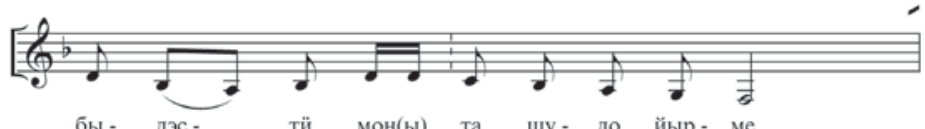

бы - дэс - тй мон(ы) та шу - до йыр - ме.

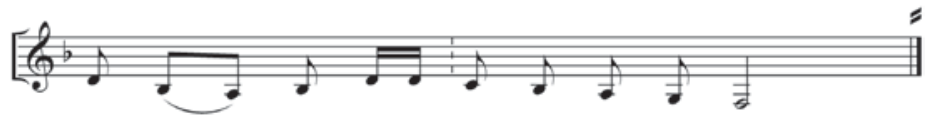

Бы - дэс- тй мон(ы) та шу - до йыр - ме.
[...]
$[\ldots]$

Dzh'ech murtlen no dzhök s'öraz When I sit down at good people's puks'on dyr(y)yam, tables,

Gurt kalykely tau karis'ko. I I thank the people of my village.

Gurt kalykely tau karis'ko. I I thank the people of my village.

Dano Ud'd'ad'i kalykenym With venerable people of val(y)che Karamas-Pel'ga, Bydestimon(y)tashudoyyr(y)me. I have raised my happy head. Bydestimon $(y)$ tashudoyyr(y)me. I have raised my happy head.

(Kyrdzh'as'... 1995) 
Dzhakapay knew and performed a huge corpus of so-called name songs, i.e. personal songs. The main distinguishing feature here is the presence in the title of the performer's name. For example, Pisl'eg Luker'yapaylen gurez, 'Aunt Pisleg (lit: Tit) Luker'ya's Tune', and Girgalen gurez, 'Girga's Tune', etc. (For more details, see Pchelovodova 2013.) For Dzhakapay, these tunes were a kind of memory of each person, encompassed in the form of musical song. She knew the story of each of these songs perfectly and could speak in detail about the former performers. Often, when singing, she interrupted the song with a surge of emotion and tears, reliving the situations the song talked about and remembering the original performer.

Some of these name songs were published as performed both solo by Dzhakapay, and with a folklore ensemble, in the collection Songs of the Southern Udmurt, which is dedicated to the singing folklore of Kiyasovo district of the Udmurt Republic (Pchelovodova, Anisimov 2020):

- Kaylo Petyr agaylen gurez-Uncle Kaylo Petyr's Tune/Song,

- Sof'yapaylen kyrdzh'an gurez - Aunt Sofia's Tune/Song (this tune was sung by a woman called Sofia when she said farewell to the people of her village on her way to the frontline during the Second World War),

- Terentey Pakapaylen Ud'd'ad'i gurtles' mözmon gurez Aunt Terentey Paka's Tune/Song. Aunt Terentey Paki was homesick for her village Karamas-Pel'ga (Ol'ga Solov'yova heard this tune from a woman called Paki, who had married into the Lyali family (Alnashi district), when once she came back to meet her kin, performing this song to express her yearning for her native village),

- Dulam Palagey apaylen gurez - Aunt Dulam Palagey's Tune/Song, 
- Pad'ey apaylen gurez - Aunt Pad'ea's Tune/Song,

- Kuz'Ondrey agaylen gurez-Uncle Kuz' Ondrey's Tune/Song (Solov'yova first heard this song from a villager from Staraya Sal'ya at the funeral of his sixteen-year-old daughter who had drowned in the river).

Other songs close to these are those called 'village tunes', characterised by geographical names. Thus, from Dzhakapay's repertoire, we have recorded Ud'd'ad'i gur, Karamas-Pel'ga's Tune; L'al'iis' vayem gur, A Tune Brought Back from Lyali; Sal'l'a gur, Staraya Sal'ya's Tune; and Böd'yalas'vayem gur, A Tune Brought Back from Varkled-Bod'ya. According to Dzhakapay, she had heard these tunes, or they had been heard by the Ud'd'ad'i people, in these villages. For example, she had never heard the Karamas-Pel'ga tune in other villages.

Another interesting text is one of the songs from Varkled-Bod'ya. Here, in addition to the loaning, we observe a kind of 'authorisation' process. The text evokes the names of people connected to the tune and from whom the singer heard the songs:

$O y$, ta gur(y)yos kin'(y)len ke no Oh, whose tunes are these, if shuylidy, you ask, yes,

Okt'abyris' Tymyr(y)shalen, oy, These tunes belong to Tymyrshi gur"yosyz. from Oktyabr'.

Okt'abyris' Tymyr(y)shalen, oy, These tunes belong to Tymyrshi gur"yosyz. from Oktyabr'.

Okt'abyris' Tymyr(y)shalen(y) This tune does not belong to gurez övöl ta, Tymyrshi from Oktyabr', 
D'em(y)yan gyne kudomylen, oy, These tunes belong only to gur"yosyz.

Dem'yan, the in-law.

D'em(y)yangynekudomylen, oy, These tunes belong only to gur"yosyz.

Dem'yan, the in-law.

D'em'yan gyne kudolen gurez It does not belong only to övöl ta,

Dem'yan, the in-law,

Choko gyne Vas'agaylen, oy, These are only Choko's and gur"yosyz. uncle Vasi's tunes.

Choko gyne Vas'agaylen, oy, These are only Choko's and gur"yosyz. uncle Vasi's tunes.

(Pchelovodova, Anisimov 2020:

Among the people of Karamas-Pel'ga there is today a tune considered to belong to Dzhakapay, called Dzhakapay's Tune, Dzhakapaylen gurez.

In conversation, when she was asked "Do you compose your songs yourself?" Dzhakapay almost always answered: "No. I live from what exists. Before me the people composed so many beautiful and warm songs." Knowing her great talent, the authors of this article understand that on the one hand, this is a manifestation of an Udmurt woman's modesty, while on the other hand it reflects the understanding of her intimate involvement with the tradition in which she lived. She had no difficulties remembering a song after only one hearing, which confirms her exceptional musical and auditory abilities. Several times we witnessed, how Dzhakapay could easily and organically include in a song any text about emotions, the moment in which we were living, her inner state, memories of her own life, etc. Improvisation for her was not something complicated - on the contrary, as she said: "All I want to say, I express it all through singing. I do not like to talk much." We have a good example of this with the song she performed on a TV show called Kyrdzh'as' 
lul-s'ulem (The Singing Soul), recorded by GTRK Udmurtia ${ }^{3}$. In this song, Dzhakapay used poetic motifs with different content, close to her life situation. We must also emphasise that singing, in the Udmurt culture, foretells a sad fate. Researchers have justly observed the ambiguous Udmurt attitude towards the art of singing: the people who know songs and have nice, strong voices are deeply respected in village society, but these performers are also understood to be unhappy people (Nurieva 1999: 87-88). This is despite the fact that Dzhakapay herself asserted it was singing and song that helped her survive the most difficult situations in her life:

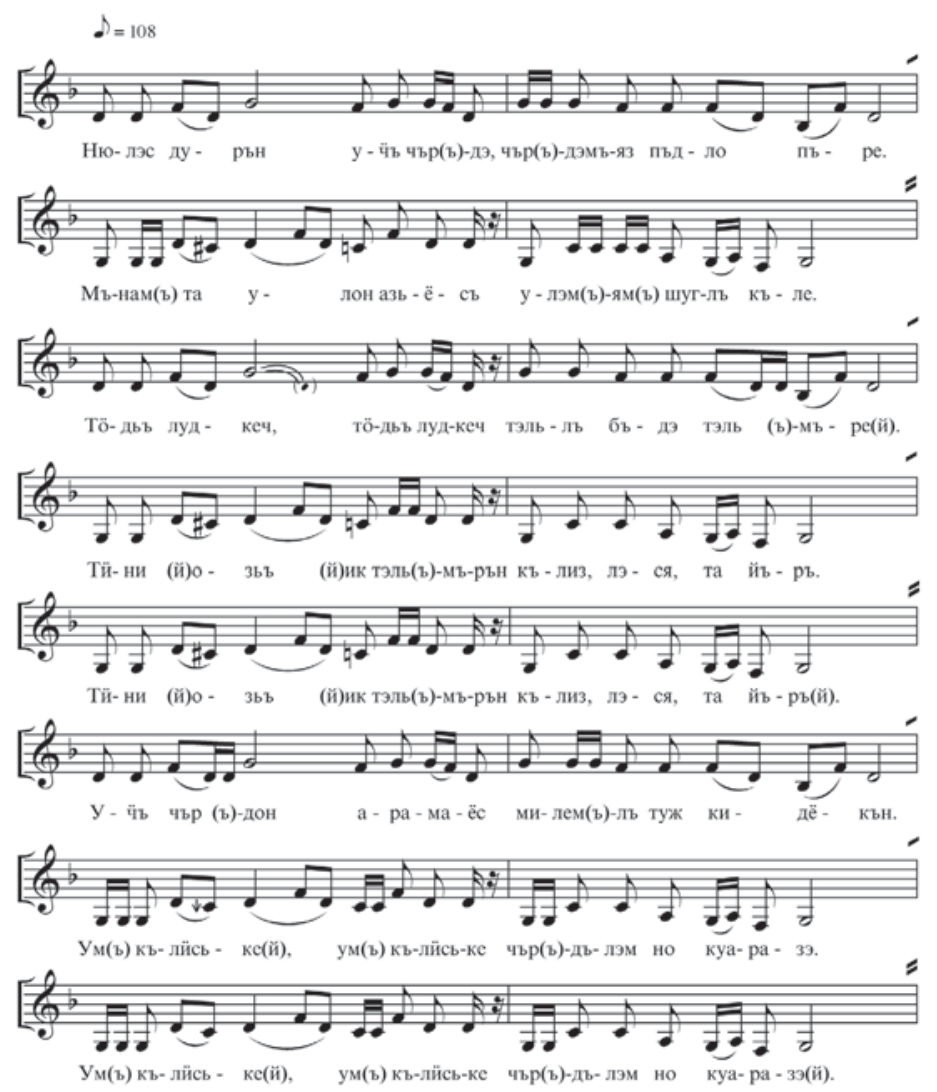


N'ules duryn utshy chyr $(y)$ de, By the forest a nightingale sings, Chyr(y)dem"yaz As far as he sang, he flew deep pydlo pyre.

Mynam(y) ta ulon az'yosy

$\operatorname{Ulem}(y) \operatorname{yam}(y)$

shugly kyle. into the forest.

This is my fate

Throughout my life, it becomes hard and harder.

Töd'y ludkech, töd'y ludkech

Tel'ly byde tel'(y)myre $(y)$.

Tin'i (y)oz'y (y)ik tel'(y)myryn Kyl'iz, les'a, ta yyry.

Tin'i (y)oz'y (y)ik tel'(y)myryn Kyl'iz, les'a, ta yyry (y).

Utshy chyr (y)don

aramayos

Mil'em(y)ly tuzh kid'okyn.

Um(y) kylis'ke(y), um(y) kylis'ke

Chyr(y)dylem no kuaraze.

Um(y) kylis'ke(y), um(y) kylis'ke Chyr(y)dylem no kuaraze(y).

Anay-atay $(y)$ tem nyl $(y)$ piyed Uy no nunal(y) tel'y (y)myre(y).

Kylis’övöl, kylis'övöl(y)

Tel'(y)myrem no kuaraze.

Kylis'övöl(y), kylis'övöl

Tel'(y)myrem no kuaraze(y).

Pichi(y)is'en

usto lui

$\operatorname{Kyr}(y) d z h$ 'any no verany $(y)$.

Kemalas'en todmo luiz,

Tatshe shudtem lueme(y).
White rabbit, white rabbit All the forest is grieving. And thus grieving Seemingly remains my fate. And thus grieving Seemingly remains my fate.

The groves where the nightingale sings, Are very far from us

We do not hear, we do not hear, His voice nor his singing.

We do not hear, we do not hear, His voice nor his singing.

The children without parents Grieve day and night.

Nobody hears, nobody hears Their voice and their grieving. Nobody hears, nobody hears Their voice and their grieving.

From my childhood I became skilled In singing and storytelling. It has long been known That I lament, unhappy, 
Kemalas'en(y) todmo luiz, Tatshe shudtem lueme(y).

Usto shuo, usto shuo, $\operatorname{Kyr}(y) d z h$ 'any no verany $(y)$. Usto luod, usto luod, Kaygu pyr(y)ti potid ke. Usto luod, usto luod $(y)$, Kaygu pyr(y)ti potid ke.
It has long been known That I lament, unhappy.

She is skilled, they say, skilled, they say In singing and storytelling. You will be skilled, you will be skilled, If you go through sorrow. You will be skilled, you will be skilled, If you go through sorrow. (Kyrdzh'as'... 1995)

Among her fellow villagers, Dzhakapay was renowned for her deep knowledge, and performances, of a large number of songs, not only Udmurt but also belonging to neighbouring peoples. Kiyasovo district is characterised by its multi-ethnic population. Here in addition to Udmurts there are Russians, Tatars and Maris. Working as a mail carrier gave her the opportunity to get acquainted with the languages of these people, and later with their singing traditions. Her further interethnic communication and interrelations offered her a wide life experience, and an interethnic heritage. She performed the songs in their original form, in Russian, Tatar and Mari, as well as in Udmurt translation. She has become a unique repository of these songs from the Udmurt's regional neighbours. Thus, for example, she had in her personal repertoire songs from the neighbouring Russian village Starozaychikovo (Kiyasovo district, now disappeared). In 2015 Dzhakapay accompanied Anna Mishina (then a doctoral student at Tartu University, Estonia) on her expedition to the Mari village of Unur-Kiyasovo, in the Kiyasovo district (6 km from Karamas-Pel'ga). Here a significant event occurred: the local Mari were in pain, or did not wish to remember 
their tunes, but when Dzhakapay herself started singing them she 'provoked' them to perform their own songs ${ }^{4}$.

Her way of actively learning the repertoires of others was also manifest during her journeys to other regions and countries for festivals. She brought back other communities' songs and performed them in her own community, in their original language as well as, sometimes, in Udmurt translation. How surprised were Hungarian, Finn, and Estonian scholars and students to hear her singing their own songs in their own languages.

Dzhakapay not only sang traditional songs, but also had in her repertoire contemporary Udmurt variety songs, thus considerably widening her musical treasure. After performing traditional songs at holiday and cultural events, she could easily change to variety songs. She was proudly in awe of the work of amateur composer Nikolai Utkin, from her village, whose songs she sang with pleasure. The opposite also happened with songs from her personal repertoire entering the variety stage. For example, Tatiana Ishmatova and Aleksandr Katkov proposed a new version of the song Zarn’i shundy dzhuzhaloz, 'The Golden Sun Rises', of Mari origin. In a duet with Alyona Timerkhanova, Nikolai Anisimov included in his stage repertoire the dancing tune from Karamas-Pel'ga Ud'd'ad'i takmak"yos, 'Karamas-Pel'ga Chastushki'. The AR-GOD project (Estonia) produced a CD that includes some songs recorded by Dzhakapay5 from different periods: Utchyyed chirdoz, 'The Nightingale Chirps'; Ekton gur, 'Dancing Tune' (Karamas-Pel'ga); Kuno gur, 'Guest Welcoming Tune'.

From our perspective, Dzhakapay is one of the rare Udmurt who has retained the archaic way of performing ritual tunes, as she observed herself: "As I sing, nobody sings now". This reality reflects the particular attitude of the performer towards Udmurt musical heritage, i.e. understanding the sacred significance of the old ritual tunes and the importance of maintaining the archaic mode of performance. Here we see the important role of a single individual as keeper and performer of cultural heritage. 
In Udmurt singing tradition there is a particular timbre, quality of voice, for the calendar tunes. The first to have considered this problem is Irina Nurieva, relying on the singing tradition of the Western (Transvyatka) Udmurts (Nurieva 1999: 83-84). About Dzhakapay's way of performing, we note her powerful transmission of sound, the singing of long musical sentences in one breath. The sound nevertheless is not loud, but is very assertive: one feels the tension in the vocal chords. Dzhakapay has retained the typical archaic intonation of the unclear third. There is another feature in Dzhakapay's interpretation that we must comment on: the monotony of her performance, a kind of detachment, which allows for a meditative state of mind. Sadly, today this form of singing within the traditional culture has been lost and is only reconstructed by student ensembles in the Republic Musical College and the Udmurt State University.

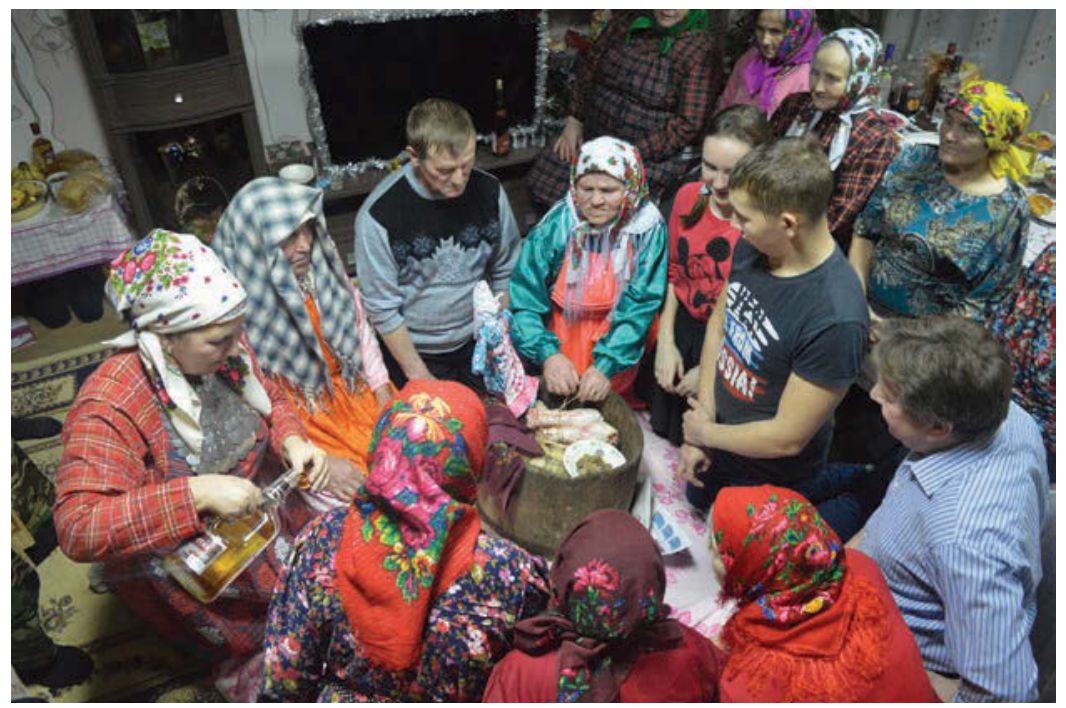

Photo 3. The yyr-pyd s'oton commemorative ritual (the giving of the head and legs (of the sacrificial animal)). Photo by Nikolai Anisimov, 2017. 
Irina Pchelovodova, Nikolai Anisimov

As an example, let us present the Tune of the Great Day, performed in 1993 by Dzhakapay, Bydzh'ynnal gur:

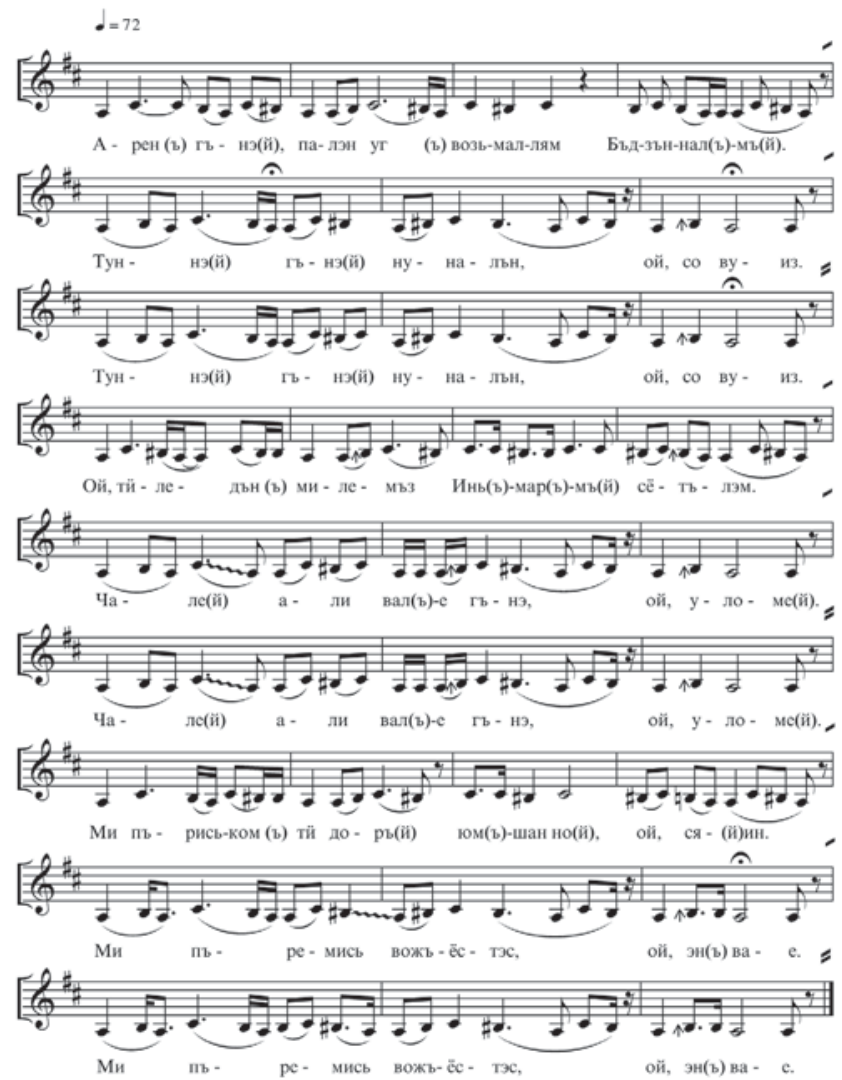

Aren $(y)$ gyne $(y)$, palen $u g(y) \quad$ Onlyinautumn ${ }^{6}$, half[ayear]Imean Voz'mal'l'am Bydydzh'ynnal(y) We have waited for our Great Day. $m y(y)$.

Tunne(y) gyne(y) nunalyn, oy, Onlyon today's day, oh, hehascome. so vuiz.

Tunne(y) gyne(y) nunalyn, oy, Onlyon today's day, oh, hehascome. so vuiz. 
Oy, til'edyn(y) mil'emyz

In'(y)mar(y)my(y) s'otylem.

Chal'e $(y)$ al'i val(y)che gyne, oy, Come on, let us live only together. ulome $(y)$.

Chal'e $(y)$ al'i vall(y)che gyne, oy, Come on, let us live only together. ulome $(y)$.

Mi pyris'kom(y) ti dory $(y)$ yum $(y) \operatorname{shan~no(y),~oy,~s'a(y)in.~}$ Mi pyremis'vozh"yostes, oy, en $(y)$ vaye.

Mi pyremis'vozh"yostes, oy, en $(y)$ vaye.

Achid(y) gyne kashamer, vinayed(y) kal'am(y)per. Tynes'tyd(y) bon ud(y) yuy(y), kin'(y)les'yuod? Tynes'tyd(y) bon ud(y) yuy(y), kin'(y)les'yuod?
Oh, to us and to you our In'mar ${ }^{7}$ has given,

When celebrating, we enter your place, Because we entered, oh, do not bear a grudge.

Because we entered, oh, do not bear a grudge.

Only you with nice cashmere, your aniseed alcohol, If you do not drink it at home, where shall you drink it? If you do not drink it at home, where shall you drink it? (Mardzh'an 1993)

Dzhakapay was not only a precious performer, she was also a keeper of folk wisdom. It is no coincidence that in her village she was jokingly called 'the computer'. This is certainly due to the personal interest she had in her native culture. Until the final day of her life, she respected and implemented traditional ontology, behaviour rules, canons of ritual and song performance, etc. - an approach that has been lost by the younger generations in the village. This explains her importance to the local community and the authority she had in it. People went to her for advice and help in the organisation of ritual ceremonies, as well as with different 
personal questions. For example, in 2017, when a family performed the commemorative yyr-pyd s'oton ritual, 'the giving of the head and legs' (of a sacrificial animal), Dzhakapay became angry with those who conversed while the participants in the ritual sang, calling the culprits to join the singing as it befitted the ritual situation. Rimma Lopatina, who organised this ritual, continuously consulted her on the actions of ritual scenarios, the implementation of rules, the uttering of formulas, the preparation of paraphernalia, etc.

Dzhakapay transmitted her knowledge and skills over long years through her participation in the Invozho local folklore ensemble at the Karamas-Pel'ga culture house. The ensemble's repertoire contains a good amount of songs generously shared by Dzhakapay on the basis of her memory and personal experience. She sang as a soloist as well as a member of the group. As a member of the group, she participated in many festivals, competitions and events at different levels, visiting many regions of Russia as well as some foreign countries. According to the ensemble's leader, Nadezhda Pakhomova, she was a kind of scientific adviser in their creative work, especially when they were preparing ritual stage reconstructions and singing ritual songs. ${ }^{8}$

In her last years, Dzhakapay was troubled by people 'chattering' a lot and singing less. She saw that life had become more sorrowful every year because tradition was disappearing and people had begun to live in isolation, lacking collective solidarity.

Another reason for the trouble she felt was the amount of knowledge that she did not want to take to her grave with her. Therefore, she started writing her memoirs in some notebooks. However, illness overtook her, which was reflected in the illegible handwriting, and some sentences remain unfinished. Now, these writings are kept by her kin. She dedicated a letter to one of the authors of this article, Nikolai Anisimov, in which she gives him her blessing and shares with him the text of one of her songs, asking him to perform it according to his wishes: 
Ulmo s'as'ka vakyte

Ton lykto, shuid, doram.

Mon voz'may, kuaz'ed sakte,

Ton öd vu, öd vu doram.

Puki sad pölyn ognam,

Kytyn ke argan shude.

Nyl kuara shuldyr

kyrdzh'a,

Tugane soly yurtte.

Puki sad pölyn ognam,

Utshy gurez

kylzysa.

Lyktemde voz'may, Az'am s'as'ka kuz'ym das'asa.

Mone pöyad shuysa, S'ulemam dzhozhan kendzhiz. Sadys' potid myn'asa, Verano kyly vuniz.

Pripev:

L’ömpu s'as’ka, l'ömpu s'as'ka,

Maly-o ton töldzh'is'kod?

Tulys kuaz'ez, yaratonez

Pös' s'ulemme kel'tis'kod.
When the apple trees bloom You said you shall come to me. I waited, dawn came [already], You did not come, you did not come to me.

I sat in the garden alone,

Somewhere the accordion plays.

The maidenly voice sings

beautifully,

My beloved helps her.

I sat in the garden alone,

Listening to the nightingale

singing.

I awaited your coming,

Preparing in front of me a gift of flowers.

Because you deceived me,

Grief inflamed my heart.

You left the garden smiling,

I forgot the words I had ready for you.

Refrain:

Wild cherry bloom, wild cherry bloom, Why did you fly away?

Spring time, love,

You leave them in my hot heart.

(From Nikolai Anisimov's

personal archive) 


\section{A precious informant}

Dzhakapay was a priceless informant for many Russian and foreign scholars and students, and this is reflected in their scientific publications. For instance, Valentina Makarova, who graduated from the Faculty of Udmurt Philology (today the Institute of Udmurt Philology, Finno-Ugristics and Journalism at the Udmurt State University) defended her graduation thesis titled "Muz"yem kol'osa, s'ulem piyala... Dzhakapaylen cheberlyko kylos portretez" ("The Earth is a Ring, the Heart is Glass: A Portrait of Aunt Jay's Creativity), in which she presents Dzhakapay's role as a unique creative personality in Udmurt culture (Makarova 2007). She summarised her conclusions thus: in Dzhakapay's repertoire, there are mainly songs that are reflections on life and people, and fewer songs about love, as they are directly connected with the singer's fate. Identifying poetic motifs in her songs (about lost youth, unhappy fate, separation), Makarova observes that one of the main themes is Solov'yova's gratefulness towards her fellow villagers for helping her at difficult moments. She makes interesting comments about a very widespread motif in Dzhakapay's songs, that of the birch. It is Dzhakapay's favourite tree, one, as we mentioned above, that played an important role in her life.

In 2010 Dzhakapay participated in Ekaterina Samodelko (Danilova)'s graduation concert for the students of the Folk Choir (today Music and Stage Arts) at the Institute of Arts and Design at the Udmurt State University.

For those students who became professional performers, Dzhakapay was an unofficial teacher in the skill of singing folk songs. In 2011, she was invited as a guest of honour, in the capacity of member of the Invozho folklore ensemble, to Maria Korepanova's first concert, which took place on the stage of the Udmurt Republic State National Theatre. 


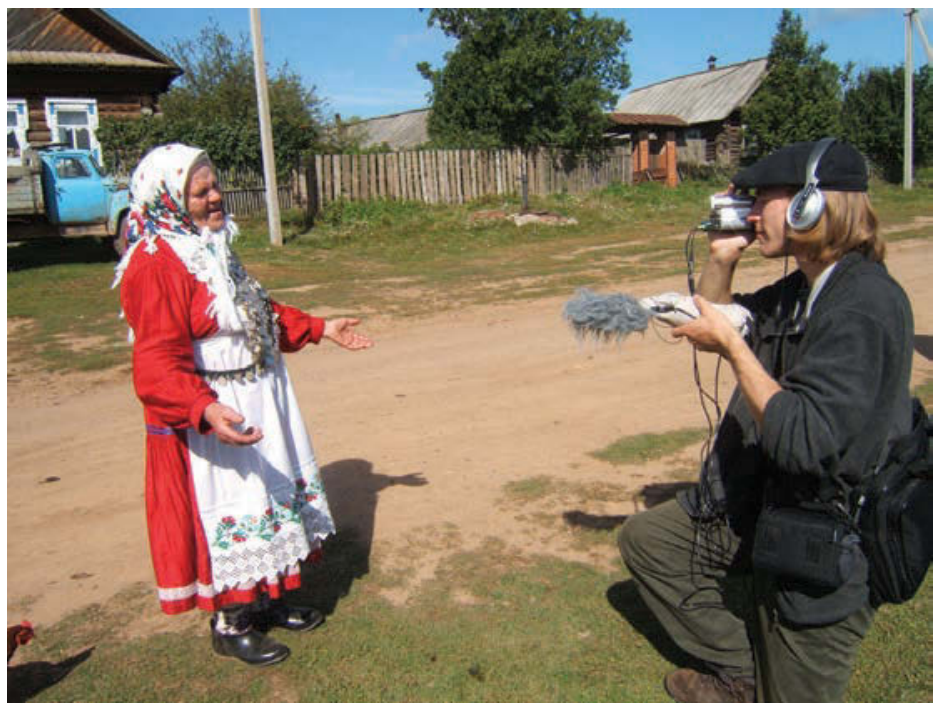

Photo 4. Dzhakapay performs for Estonian scholars 2005. Photo Eva Toulouze.

The Udmurt folklorist, doctor and professor Tatiana Vladykna dedicated her monograph Udmurt Folklore: Problems of Genre Evolution and Systematics ("Udmurtskiy fol'klor: problemy zhanrovoy evolyutsii i sistematiki” (Vladykina 1997) to Solv'yova and those who know the Udmurt folk traditions: "Dzhaky apayly no tros-tros muket'yosyzly, kin ut'iz no ut'e na udmurt kalykmyles' viz'nodze no kinen shud us'iz mynym pumis'kyny, - yybyrtysa”('To Aunt Dzhaky and many, many others who preserved and go on preserving our Udmurt people's folk wisdom and whom I had the chance to meet - with my deep respect.') (Vladykina 1997: 3).

In recent years the authors of this article also turned to her performing skills and deep knowledge. Thus, Dzhakapay was of great assistance when they gathered material for the Songs of the Southern Udmurt collection, dedicated to the non-ritual musical folklore of Kiyasovo district Udmurts (Pchelovodova, Anisimov 2020). 
Thirty-two of the songs are recorded in her interpretation, either solo or with an ensemble:

- $\quad$ state radio and television channel Udmurtia (Documentary films: Mardzh'an ('Pearl') 1993; Kyrdzh'as' lul-s'ulem ('Singing Soul') 1995; Ut'is' ('The Keeper') 2014;

- state radio and television channel Sankt-Petersburg (Letters from the Province, cycle of television programmes);

- in 2005 local TV in Riga filmed the Baltic Festival, in which the Karamas-Pel'ga folk ensemble took part;

- First Channel (participation in the Minute of Glory television show with the Invozho folk ensemble, 2010).

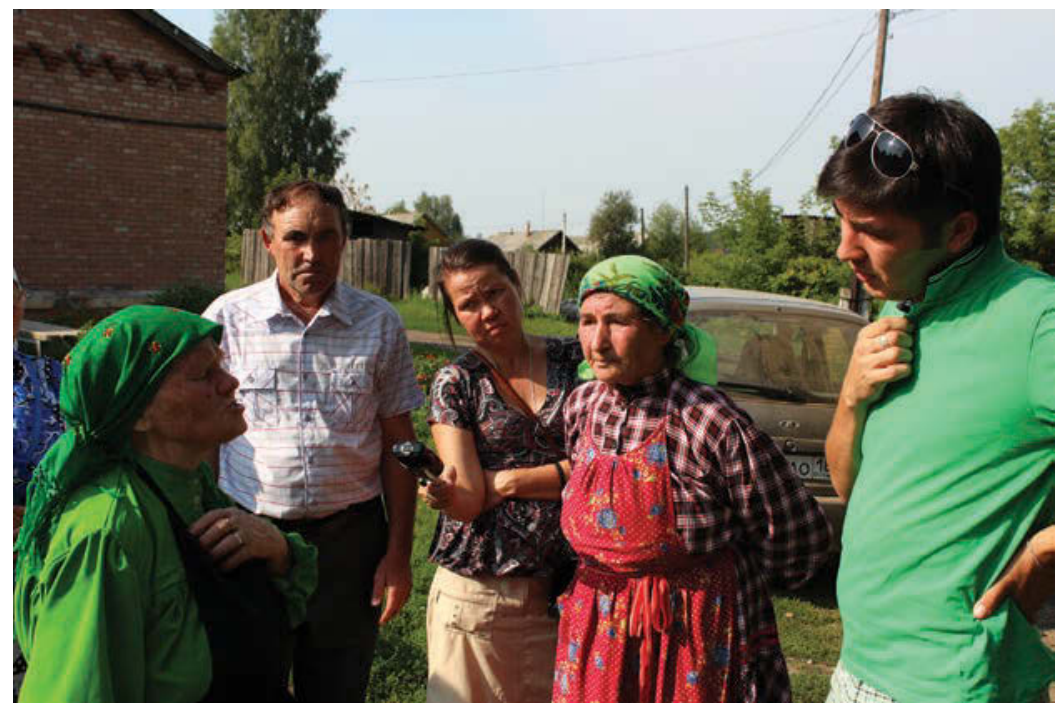

Photo 5. The authors of the article meet Dzhakapay, 2013. Photo Denis Kornilov. 
Photo 6. Dzhakapay in 2016. Photo Nikolai Anisimov.

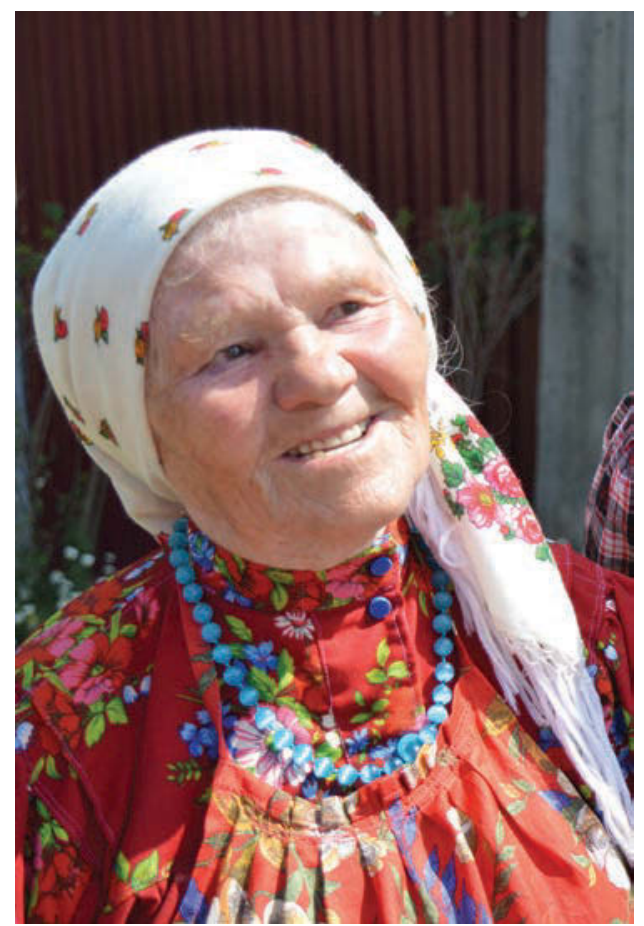

\section{In place of a conclusion}

Dzhakapay's demise on June 26th 2018 represented a great loss to the Udmurt culture. Much of her knowledge remained unrecorded, and what is recorded has not yet found a researcher so that it can enrich Udmurt science and culture. However, we may now assert with confidence that even the first research into the creative expression of an individual using Dzhakapay as an example and following her interaction with the canons of culture, illuminates how mechanisms of the collective and the individual function in the folklore tradition. Most precious are Dzhakapay's comments 
about cultural processes, as collective knowledge is often spread through the personal discourse of the singer or storyteller.

We plan several projects connected with Dzhakapay's unique personality:

- The young Udmurt cameraman Denis Kornilov, junior researcher at the Udmurt Research Institute, is preparing a film about her;

- Singer Dr. Maria Korepanova is preparing an album of songs sung by Dzhakapay both in her personal interpretation and in cooperation with other musicians;

- The authors of the article plan a separate book dedicated to her singing creation;

- In Karamas-Pel'ga, her son-in-law is reconstructing her native home so that it can function as a house museum in memory of Dzhakapay.

\section{Notes}

1 Around $8 \mathrm{~kg}$.

${ }^{2}$ Here and throughout, the Russian translations of the Udmurt texts are by the authors of the article. The English translations are made by the article's translator.

3 State radio and television channel.

4 Oral information from Anna Mishina, 2019.

5 The AR-GOD project (Estonia) includes Udmurt and Estonian musicians Maria Korepanova, Nikolai Anisimov and Toivo Sõmer. The group was created in 2014. The characteristic of their performance is a combination of traditional Udmurt and Besserman songs accompanied by ethnic musical instruments. 
6 According to Udmurt scholars, the word ar, which in modern Udmurt means "year" (as calendar year), comes from the Permian *ar "autumn" and in its very first meaning is to be found, for example, in calendar and ritual songs (Vladykina, Glukhova 2011: 1415). "In the coincidence of the concepts of autumn and year, the Udmurt folklorists perceive the great importance of the autumn and winter period, probably in connection with the archaic calculation of time, when the new year started in Autumn" (Anisimov 2017: 102).

7 In'mar - theonym of the supreme God living in heaven.

8 Oral information by N. Pakhomova, 2019.

\section{Sources}

Kto my. Armiye kel'an [Farewell to the Recruit]. https://youtu.be/nICe_ P8DhoI (accessed 26 November 2019).

Kyrdzh'akum bördis'ko, bördykum kyrdzh'as'ko [When I Sing I Weep, when I Weep I Sing]. O. Solov'yova; recorded by L. Tikhonova. Udmurt dun'n'e. 9. November 2012, pp. 6, 11. https://elibrary.unatlib.ru/dspace/ dsview.html (accessed 25 November 2019).

Letters from the province. https://youtu.be/EhYDW8KQpk4 (accessed 26 November 2019).

The holiday Akashka. Karamas-Pel'ga, Kiyasovo district, Udmurt Republic. https://youtu.be/ AhuPuJH0Vc4 (accessed 26 November 2019).

Udmurtia, I love you. https://youtu.be/AjXcPlnyxds (accessed 26 November 2019).

\section{References}

Alpatov, S. 2014. Skazochnik-balagur: lichnost' i tvorcheskiy tip [Joker Storyteller: Personality and Creative Type]. Lichnost'v traditsionnoy kul'ture [Personality in traditional culture]. Moscow: State Institute of Art Studies, pp. 41-59. 
Anisimov, N. 2017. "Dialog mirov" v matritse kommunikativnogo povedeniya udmurtov ["Dialogue of the Worlds" in the Matrix of Communicative Behavior of the Udmurts]. Tartu: University of Tartu Press.

Lichnost'v traditsionnoy kul'ture [Personality in Traditional Culture] 2014. Moscow: State Institute of Art Studies.

Makarova, V. 2007. Zemlya-koleso, serdtse-steklo... Tvorcheskiy portret teti Soyki: dipl. rabota [The Earth is a Wheel, the Heart is Glass ... Creative Portrait of Aunt Jay]. Izhevsk: BA work, manuscript.

Nurieva, I. 1999. Muzyka v obryadovoy kul'ture zavyatskikh udmurtov [Music in the Ritual Culture of Trans-Vyatka Udmurts]. Izhevsk: Udmurtskiy institut istorii, yazyka i literatury Uralskogo otdeleniya Rossiyskoy akademii nauk.

Nurieva, I. 2014. Udmurtskaya muzykal'no-pesennaya traditsiya: spetsifika zhanroobrazovaniya i funktsionirovaniya: diss. na soisk. uchenoy. st. doktora iskusstvovedeniya [Udmurt Musical Song Tradition: Specifics of Genre Formation and Functioning]. Izhevsk: UdGU, PHD dissertation.

Pchelovodova, I., Anisimov, N. 2020. Pesni yuzhnykh udmurtov. Vyp. 4. [Songs of Southern Udmurts. Vol. 4]. Izhevsk-Tartu: UdmFITs UrO RAN; Estonian Literary Museum.

Pchelovodova I. 2013. Udmurtskaya pesennaya lirika: ot motiva $k$ syuzhetu [Udmurt Song Lyrics: From Motive to Plot]. Izhevsk: Udmurtskiy institut istorii, yazyka i literatury Uralskogo otdeleniya Rossiyskoy akademii nauk.

Pentikäinen, J. 1971. Marina Takalon uskonto: Uskontoantropologinen tutkimus. [Marina Takalo's Religiosity: A Research in Anthropology of Religion]. Suomalaisen Kirjallisuuden Seuran toimituksia 299. Helsinki: Suomalaisen Kirjallisuuden Seura.

Pino, V. 2000. Elukutseline tegevus - setu rahvalaulik (Darja Pisumaa, alias Hilana Taarka Vasila Taarka) [Professional Activity - Setu Folk Singer (Darja Pisumaa, aka Hilana Taarka Vasila Taarka)]. Siirmann, Niina (ed.). Minevikumälestusi II. Põlvamaa kodulookogumik [Memories of the Past II. Põlva County Local History Collection]. Põlva: Põlva, pp. 79-86. 
Romodin, A. 2009. Chelovek tvoryashchiy. Muzykant v traditsionnoy kul'ture [Creative Man. Musician in Traditional Culture]. St. Petersburg: GNII "Institute of Art History".

Starodubtseva, S. 1999. Oh, rospechal'noye moyo serdechko (pesni iz repertuara Natal'i Vlasovoy) [Oh, My Sad Heart (Songs from the Repertoire of Natalia Vlasova)]. Vol. 1. Izhevsk: Udmurtskiy institut istorii, yazyka i literatury Uralskogo otdeleniya Rossiyskoy akademii nauk.

Vladykina, T., Glukhova, G. 2011. Ar-god-bergan: Obryady i prazdniki udmurtskogo kalendar'ya [Year-Circle: Rituals and Celebrations of the Udmurt Calendar]. Izhevsk: Udmurtskiy universitet.

Zhulanova, N. 2014. Lichnost' v traditsionnoy muzykal'noy kul'ture: ot sotsiokul'turnykh roley k unikal'nym individual'nostyam [Personality in Traditional Musical Culture: From Sociocultural Roles to Unique Personalities]. In: Lichnost' $v$ traditsionnoy kul'ture [Personality in traditional culture]. Moscow: State Institute of Art Studies, pp. 14-40.

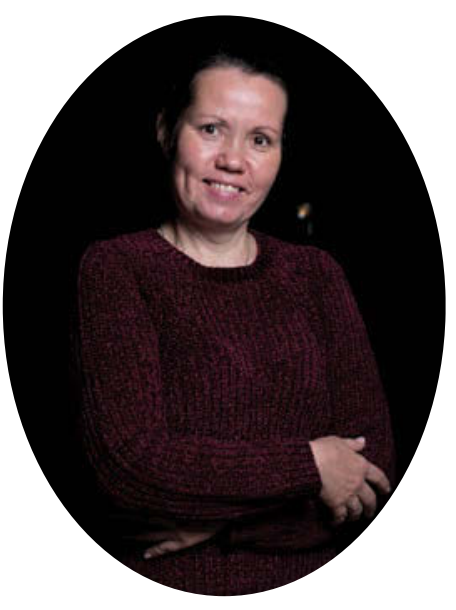

Irina Pchelovodova $(\mathrm{PhD})$ is an ethnomusicologist and a research associate at the Udmurt Institute for Research in History, Language and Literature (Udmurt Federal Research Centre of the Ural Branch of the Russian Academy of Sciences). She is interested in Udmurt folk music, folk song and folk instruments. She teaches at the University and at the Music college; she is the leader of the folklore and ethnographic musical group Chipchirgan.

e-mail: orimush@mail.ru 


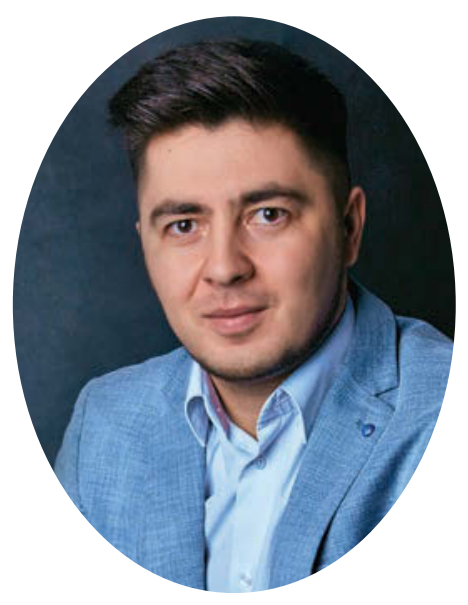

Nikolai Anisimov ( $\mathrm{PhD}$ ) is a researcher at the Department of Folkloristics at the Estonian Literary Museum, Estonia, and at the Department of Philological Studies at the Udmurt Institute for Research in History, Language and Literature (Udmurt Federal Research Centre of the Ural Branch of the Russian Academy of Sciences). His main field of interest is Udmurt traditional and contemporary culture, and more precisely, the Udmurt living ancestors' cult, and their singing tradition.

e-mail: nikolai.anisimov@folklore.ee 